\title{
Arsenic contamination in India: Causes, effects and treatment methods
}

\author{
Rishabh Tiwari $^{1}$, Satwik $^{2 *}$, Prateek Khare ${ }^{1}$, Satyam Rai $^{1}$ \\ 1,2*3,4 Department of Chemical Engineering, Madan Mohan Malaviya University of Technology, Gorakhpur, Uttar Pradesh, INDIA \\ "Corresponding Author: e-mail: satwik.mmmut@gmail.com
}

\begin{abstract}
Herein the present study focuses on arsenic (As) contamination in groundwater, which plagues a vast section of the population of the world. Even the conservative estimates by the World Health Organization (WHO) estimate the number of people plagued by arsenic contaminated drinking water to be around 140-200 million. The Ganga- Brahmaputra fluvial plains in India and Padma-Meghna fluvial plains in Bangladesh are said to be one of the worst groundwater calamities to the humans. The Arsenic levels in drinking water in some of the most populated states in India are disproportionately higher than those defined by WHO guidelines. The paper, thus, delves into the anomaly in permissible limits defined by WHO and regional governments and its consequential effects. It briefly analyses the major sources of Arsenic contamination and its health effects in India. The study also looks closely into the states and districts plagued by the As contamination and explores the prominent treatment methods employed in as removal from the drinking water.
\end{abstract}

Keywords: Arsenic, Adsorption, Geogenic, Arsenopyrite, Oxidation treatment

DOI: http://dx.doi.org/10.4314/ijest.v13i1.22S

Cite this article as:

Tiwari R., Satwik, Khare P., Rai S. 2021. Arsenic contamination in India: Causes, effects and treatment methods. International Journal of Engineering, Science and Technology, Vol. 13, No. 1, pp. 146-152. doi: 10.4314/ijest.v13i1.22S

Received: December 1, 2019; Accepted: February 5, 2021; Final acceptance in revised form: March 31, 2021

This paper was earlier presented at the International Conference on Energy, Environment \& Material Sciences (ICE2M), 1-3 December 2019 and substantially improved for this Special Issue. Guest Editor: Dr. Sri Niwas Singh, Professor (HAG), Department of Electrical Engineering, Indian Institute of Technology Kanpur, 208016 (U.P.) India, former Vice-Chancellor, Madan Mohan Malviya University of Technology Gorakhpur (April 2017 to July 2020).

\section{Introduction}

Arsenic is one of the naturally occurring elements in Earth's crust and atmosphere. Its compounds are known to be poisonous in nature and pose serious health threats to organisms. Arsenic compounds are categorized into two groups: organic and inorganic. While the organic compounds of As, containing As-C bonds, are less common in occurrence, the inorganic compounds are rather often present around us. Most abundant compounds of As are in conjunction with Sulphur (as sulphides), oxygen (oxides) or carbonates. It is this inorganic As that poses health threats when it enters the human body through various sources such as water, food or sometimes air. While the atmospheric occurrence of As is attributed to volcanic eruptions, fires, etc., or anthropogenic sources like industrial smokes, etc., its threat level is rather low in comparison with its occurrence in other forms. It is only when As is present in high concentrations in air due to industrial effluents and incomplete fossil fuel combustion, that it poses significant threats.

However, unlike its formidable presence in atmosphere, As asserts its characters when found in water sources and land. It is one of the ten chemicals in the list of 'Chemicals of Public Health Concern' by WHO and affects around 140 million people from around 50 countries across the world (WHO, 2018). Apart from developing countries like India, China, Argentina, Mexico, 
Bangladesh, etc., even developed countries like United States of America is suffering from As contamination. The most common medium by which As enters the human body is drinking water and its presence in soil, rocks and other formations is the leading cause of water contamination with As, be it groundwater or surface water. In this paper, we thus delve in the sources of As contaminations, its threat levels and impact in India and then look into the methods of mitigating and treating As contaminated water.

\section{Permissible limits of arsenic for human body}

Although the WHO has established a standard value of desirable limit of As, there are quite differing and varying standards for permissible limits across the world. The provisional guideline value for As in drinking water, as set by WHO, is $10 \mu \mathrm{g} / \mathrm{l}$ or 0.01 $\mathrm{mg} / \mathrm{l}$ (Edition, 2011). This is, however a provisional limit, which thus gives flexibility to regional institutions and governments to determine the limits in accordance with the regional variations and conditions. The Indian Government thus specifies the permissible limit of As in drinking water, in absence of alternative sources, as $50 \mu \mathrm{g} / \mathrm{l}$ or $0.05 \mathrm{mg} / \mathrm{l}$ (Hossain et al., 2005).

There are some basic assumptions, and the stemming anomalies, on which the permissible limits are calculated needs to understood in order to be able better comprehend the consequential impact it has on health of populations exposed to As contaminated water. The first and the basic underlying assumption, which often holds true for the vast sections of population, is the 'absence of alternative source' of intake of As, i.e., the above values are the permissible limits when a person is not exposed to any other form of As intake except through drinking water. This assumption holds true generally as the other sources of As intake, like air and food are rather less significant. However, recent studies have suggested presence significant levels of As in some food grains and in Tobacco products, which we explore in the next section. Thus, in order to ensure health safety, the actual limit for As intake for a populace exposed to above two, or more similar factors, should be significantly lower than the prescribed limits. As stated earlier, these factors are often absent, and more often neglected.

The second assumption on which the WHO calculations are based is that an average adult (of around $60 \mathrm{~kg}$ ) consumes around $2 \mathrm{~L}$ of water daily (on an average). This assumption again yields a result that may not reflect the actual permissible limits for India. It is found that water consumption and drinking patterns differ from individuals to individuals, culture to culture and nation to nation. People in India, being a tropical and thus warmer country, consume water higher than those in western and colder climates. According to a study conducted by M. Amir Hossain, Bhaskar Das, and other group of researchers to determine the water consumption patterns in West Bengal (Hossain et al., 2013), the average intake of water per person per day was around 3.12 \pm 1.17 $\mathrm{L} /$ day. This is only for the direct intake of water. The indirect intake of water was found to be around $2.15 \mathrm{~L}$ per person per day. Although these figures had slight variations depending upon the age group and gender on account of the tasks that they undertake, the generalized average value does hold true. Thus, average total (direct + indirect) water intake was calculated to be 4.92 L/person/day. Categorically, the total intake for adult males, females and children was 6.10, 4.84, and 3.24 L/person/day, respectively. Considering the fact that most parts of India, except the Himalayas, have tropical climate, these figures on water consumption can be thought of to be significantly valid for a large section of population of India.

Taking into account the water consumption patterns of India, the permissible limit of As in water should be significantly lower than the desirable limit of $0.01 \mathrm{mg} / \mathrm{l}$ set by WHO. The permissible limit of $0.05 \mathrm{mg} / \mathrm{l}$, which is five times the WHO standard, exposes the people to significant levels of health threats and the high-water consumption due to climatic conditions further compounds the problem. Although the desirable limit set by India too is $0.01 \mathrm{mg} / \mathrm{l}$, but for practical purposes the limit of $0.05 \mathrm{mg} / \mathrm{l}$ is the one adhered to. Bangladesh, like India, and many other countries, has set the permissible limit to $0.05 \mathrm{mg} / \mathrm{l}$ in order to first target and rescue the people exposed to deadly levels of As contamination. While the explanations behind such standards may seem to be pragmatic, the exposure to such levels of contaminations over a long period of time is not sustainable.

\section{Sources of arsenic in groundwater}

The occurrence of As in environment has primarily been attributed to two types of sources: geogenic and anthropogenic. A major concern emerging from recent studies is the arsenic. Naturally, it is found in some of the rock formations, and otherwise released in industrial discharges and agricultural run-offs. These run-offs and chemical pesticides consequently contaminate the groundwater as well pose significant threat of entering the food chain.

As is found to be present in large proportions in around 200 minerals (Bissen and Frimmel, 2003). In addition to these minerals, the alluvial sediments that contain As in high proportions contaminate, on dissolution or desorption, the groundwater and surface water in deltas (Matschullat, 2000). Some sulfidic minerals are found to contain As in large proportions and this further leads enhances the concentration of semimetals in water (Borba et al., 2003).

Arsenopyrite, which is found in abundance, is one of the most common mineral source of Arsenic. It is generally found in anaerobic conditions and other minerals, such as phosphates and silicates, that have the tendency to form rocky structures (Smedley and Kinniburgh, 2002). Sulphur deputizes As in the crystal lattice of its many mineral forms. As is present in its lower(reduced) oxidation state in two typical minerals of Realgar $\left(\mathrm{As}_{4} \mathrm{~S}_{4}\right)$ and orpiment $\left(\mathrm{As}_{2} \mathrm{~S}_{3}\right)$ and in its higher oxidation state in arsenolite $\left(\mathrm{As}_{2} \mathrm{O}_{3}\right)$. As is found in varying proportions ranging from three to ten micrograms per $\mathrm{kg}$ as a function of the specific features of the minerals containing it. In comparison to areas containing other oxides, the areas with elevated content of oxides of 
iron and other metals in hydrous state are found to have larger As content in their sediments. Although the mechanism of release of As in groundwater has not been well established, the existent studies suggest the dissolution of metals and bacterial activities associated with the same as prominent cause of As concentration in water. In conjunction with this bacterial activity, the reductive dissolution of the iron and aluminium oxides is considered as the leading cause of As release in groundwater and the process is also found detrimental to the movability of the As ions.

While these geographical processes are considered to be the leading cause of contamination of groundwater with As, the anthropogenic sources also need to be considered, the effects of which in groundwater contamination is rather less pronounced. Fossil fuel combustion, mining and use of chemicals in agriculture, that are often found to contain As, are the leading mancontrolled sources of As release in environment. The combustion of coal has a widespread impact on the environment. Its combustion releases $\mathrm{As}_{4} \mathrm{O}_{6}$ and this many a times ends up in water reservoirs through the condensation cycles in flue systems (Bissen and Frimmel, 2003).

The principal occurrence of As in groundwater is in the form of oxy anions, which are in turn found in two states: arsenic (+III) called as (arsenite) and arsenic (+V) which is called as arsenate (Ferguson and Gavis, 1972). The twain of these states can be found in the $\mathrm{pH}$ range of 6-9. The neutral species are the $\mathrm{H} 3 \mathrm{AsO} 3$ while the primary arsenate species are monovalent $\mathrm{H}_{2} \mathrm{As}_{\mathrm{O}-4}$ and divalent $\mathrm{HAs}_{\mathrm{O}-4}$. Which of the two oxidation states, either As (III) or As (V), then becomes dominant in the groundwater is a function of its encompassing conditions and the geological sources from which it originates (Welch et al., 1988). The toxic nature and the ease of removal of arsenic is different for As (III) and As (V). As (III) is found to be more harmful in nature due to its relatively stable and non-reactive nature in comparison with As (+5) (Shankar and Shanker, 2014). This relative stability makes it even more difficult to remove As(III) from water and thus poses high threat if it enters the human body. The different processes that convert the solid As into liquid from are detrimental for the concentration levels of As in the water. One of the main causes of release of As in groundwater is the dissolution of oxyhydroxides of iron in the groundwater due to microbial activity (Guo et al., 2011).

\section{Regions affected by arsenic contamination}

The various sources of arsenic that contaminate water across the subcontinent affect the lives of millions of people directly and indirectly. India is badly affected by consumption of groundwater contaminated by arsenic. In response to a question in parliament, the Government of India acknowledged that 1.47 crore $(14.7$ million) people are at the frontlines of arsenic contamination of potable water across 16,889 areas (Hindustantimes, 2019). As per information entered by different States of India in the Integrated Management Information System (IMIS) of this Ministry as on 31.03.2019, there are 60,365 habitations affected by various chemical contaminants. Numbers of habitations affected by different chemical contaminants are given below in Table 1 (Jalshkti, 2019).

Table 1. Numbers of habitations affected by different chemical contaminants

\begin{tabular}{|c|c|c|c|c|c|}
\hline Fluoride & Iron & Arsenic & Salinity & Nitrate & $\begin{array}{c}\text { Heavy } \\
\text { Metals }\end{array}$ \\
\hline 9,001 & 15,813 & 18,600 & 1,446 & 2,162 & 60,365 \\
\hline
\end{tabular}

The first incidences of detection of As in groundwater in India can be traced back to the Bengal region in the last two-three decades of concluded millennia. Bengal Basin, which is formed by the delta of Ganga-Brahmputra rivers, is the hotbed of the As contamination of potable water. The reason for this has been attributed to the large volumes of the arsenic rich sediments brought down by these rivers during the Pleistocene and Holocene periods. Within India west Bengal has 78 blocks in 9 districts with arsenic permissible limit of $0.05 \mathrm{mg} / \mathrm{lt}$. One of the flashiest areas of concern is the eastern side of Bhagirati river in Malda. Also the regions of north and south of Parganas are greatly affected. Some of the western side of Hooghly and Howrah are arsenic contaminated. Mainly arsenic is evident up to the depth of $80 \mathrm{~m}$. The deeper you go the lesser is water affected by arsenic.

Arsenic has also been detected in the state of Uttar Pradesh, Bihar, Assam, Chhattisgarh, Jharkhand and Karnataka. In Bihar, West Bengal and Uttar Pradesh mostly it is seen in alluvial soil while in Chhattisgarh the arsenic contamination is mostly visible in volcanic rocks (Jalshkti, 2019).

Table 2 States with districts having arsenic content $(0.01-0.06 \mathrm{mg} / \mathrm{l})$

\begin{tabular}{|c|l|l|}
\hline S.No. & \multicolumn{1}{|c|}{ State } & \multicolumn{1}{c|}{ Districts with As(0.01-0.1mg/l) } \\
\hline 1. & Andhra Pradesh & Goontoor, Kurnul, Nellorie \\
\hline 2. & Assam & Gola, Jorhati, Lakhimpuri, Nayagaon, Nalibari, Sibasagar, Sonpur \\
\hline 3. & Bihar & $\begin{array}{l}\text { Begusaraae, Bhaagalpur, Baxar, Dharbhanga, East and West } \\
\text { Champaaran, Gopaalganj, Hajipur, Chapra }\end{array}$ \\
\hline 4. & Chhattisgarh & Raijnandagaon \\
\hline
\end{tabular}


Table 2. (Cont'd) States with districts having arsenic content $(0.01-0.06 \mathrm{mg} / \mathrm{l})$

\begin{tabular}{|c|l|l|}
\hline S.No. & \multicolumn{1}{|c|}{ State } & \multicolumn{1}{c|}{ Districts with As(0.01-0.1mg/l) } \\
\hline 5. & Delhi & Whole of it \\
\hline 6. & Daman \& Diu & Diu \\
\hline 7. & Gujarat & $\begin{array}{l}\text { Amareli, Aanand, Bharuch, Bhavnagar, Dahod, Gandhinagar, Kachh, } \\
\text { Rajkot, Vadodara }\end{array}$ \\
\hline 8. & Haryana & Bhiwanii, Mahendragarh, Palwaal, Rohtakk, Sirsaa, Sonipat \\
\hline 9. & Himachal Pradesh & Kangra \\
\hline 10. & Jammu \& Kashmir & Jammu \\
\hline 11. & Jharkhand & Saahebganj \\
\hline 12. & Karnataka & Raichuur, Yaadgir \\
\hline 13. & Madhya Pradesh & $\begin{array}{l}\text { Beetul, Burhaanpur, } \\
\text { Nemuch, Umariaa }\end{array}$ \\
\hline 14. & Odisha & Gajpati \\
\hline 15. & Punjab & Faridcoat, Gurdaaspur, Hoshiarpur, Sangrur, Tarn Taran \\
\hline 17. & Rajasthan & Ganga Nagar \\
\hline 18. & Telangana & Nalgondaa \\
\hline 19. & Uttar Pradesh & Aazamgarh, Badau, Bahraich, Basti, Deoria, Gorakhpur, Jhansi \\
\hline 20. & West Bengal & Hooghli, Howraah, North south Parganas \\
\hline
\end{tabular}

\section{Health effect of arsenic contamination}

Arsenic is very fatal cancerous and harmful contaminant of drinking water. It occurs in both organic and inorganic forms. Organic As is less dangerous while inorganic As is very much harmful as well as carcinogenic. This has been extensively emphasized in very well-known studies. Studies prove that it actually affects the gene proliferation process. It also deforms the signal transduction pathway. It also damages the cell repairing, cycling and differentiating power of the DNA. Some of the transduction process that it hinders are protein 53 signaling thoroughfare, Nrf2- mediated thoroughfare, MAPK thoroughfare. Not only carcinogenic but it causes other diseases like dermal, cardiovascular, hypertension. Sometimes it also causes diabetes. When the concentration increases to $0.05 \mathrm{mg} / \mathrm{kg} / \mathrm{day}$ or more than this, then it stems many digestive system issues like stomach ache, vomiting etc. It is so much harmful in this case that it may lead to even death and coma. Continuous poisoning for 6 months with arsenic causes lung disease, skin lesion and hyperpigmentation. It was 2011 that USEPA changed the 50mg/lt. old standard to $10 \mathrm{mg} / \mathrm{l}$ while India still uses the same old standard. After many years of this still we could witness the skin lesions. Arsenic contamination is also transmitted through rice which is grown in Bengal basin is also a matter of debate.

\section{Arsenic treatment method}

There are multiple treatment methods that are used to for arsenic removal from water. Depending on the concentration level, scale of treatment and costs, different methods and technologies are used. Arsenic in its pentavalent state-As(V) is more mobile as compared to its trivalent state-As(III) which is predominantly non-charged below a pH of 9.2. Thus, most of the treatment techniques focus on removing Arsenic in the form of $\mathrm{As}(\mathrm{V})$ rather than $\mathrm{As}(\mathrm{III})$. In solutions with high concentration of As(III), it is first converted to $\mathrm{As}(\mathrm{V})$ through oxidation by various means and then subsequently removed by various techniques. The oxidation techniques utilized are primarily of three types: 1) Active Oxidation by hypochlorite, permanganate, etc. 2) Passive oxidation by the storing water in air for longer periods 3) In-situ oxidation by exposing water to air and running it back in wells. Another effective method, although less economical, of removal of arsenic is the coagulation and filtration method. It utilizes a coagulant, such as lime, that coagulates the As and then co- precipitates the same with other metal hydroxides or salts. The most promising results of As removal have been shown by the adsorption technique. It utilizes different kinds of adsorbents like activated carbon, granular ferric hydroxide, hydrous cerium oxide, etc.

Of particular interest in among the adsorbents has been the shape and structure of adsorptive surface so as to maximize the adsorption. Other minor techniques used in Arsenic treatment are Membrane techniques and Ion-Exchange. Membrane technique uses two kinds of membranes for arsenic removal: low-pressure membranes such as microfiltration and ultrafiltration and highpressure membranes such as nano-filtration and reverse osmosis. This technique is independent on the $\mathrm{pH}$ of the water and other solutes but is affected by the presence of colloidal matters. Ion exchange method employs charged medium, such as synthetic resins, of defined ion exchange capacity to remove Arsenic. It is slightly dependent on $\mathrm{pH}$ of water and As(III), being uncharged, cannot be removed by this method. In the case of adsorption, several research projects have been proposed to chart out adsorbents which are cheaper and also efficient for removal of Arsenic from drinking water. Many adsorbents are developed and their loading capacity was compared with other alternatives. Steps are being taken to make adsorbents superior to commercially available adsorbents for higher range of ambient conditions i.e. $\mathrm{pH} \&$ temperature, having more surface area and more of adsorption 
capacity. Further, suitable wrapping and maintaining of the build material by proper techniques is established to have their great use with least effect on the efficiency

\subsection{Oxidation and filtration method}

Most of the chemicals like $\mathrm{Cl}, \mathrm{H} 2 \mathrm{O} 2, \mathrm{Ca}(\mathrm{ClO}) 2$, or $\mathrm{KMO} 4$ are mainly used to oxidise As3+ to As5+ . If proper care is not taken, it releases many unwanted by products. UV oxidises only $70 \%$ arsenic. When water is impaled with sulphite, UV photo- oxidation shows extremely good results for arsenic 3+ oxidation kinetics study by aqueous chlorine and ozone for drinking water treatment. Arsenic oxidation process is sometimes carried out using many bacteria in groundwater as catalyst. This method is favorable when iron and manganese are present in addition to arsenic. Iron- and manganese- oxidizing bacteria are mainly utilized to convert As3+ to As5+ which is naturally present in groundwater (Bibi et al., 2017).

\subsection{Co-precipitation method}

Co-Precipitation is a technique which is mostly used in small scale to remove arsenic contamination from drinking water. It is done in 3 steps:(i) lime soothing (ii)gravity filtration and coagulating technique. (iii)and finally micro filtration. Lime soothing is very costly for removing only arsenic and therefore it is not that economical. Nevertheless, if it is used for removal of water hardness with arsenic removal then it is a good method. More lime is added to alter the $\mathrm{pH}$ and make it more than 10 to remove arsenic. At this $\mathrm{pH}$ range $\mathrm{Mg}(\mathrm{OH})_{2}$ precipitates and arsenic is removed by the method of co- precipitation. Doing the same by $\mathrm{CaCO}_{3}$ is not that good for removal of As (Fields et al., 2000). In India the method of co precipitation is being applied in a cost effective way in household arsenic remediation technology in west Bengal. This project is run under the guidance of Dr. Pahari Basu, PI, Save the Environment, Kolkata (DST-gov-in, 2019). It is has been tested in 24 Paraganas (North) of West Bengal. 250 of such filters have been set-up in the village Lalmath of Nadia district, and they cater to the drinking water needs of around thousand people residing in this village (DST-gov-in, 2019).

\subsection{Adsorption method}

Adsorption is the most widely used technology for treatment of water containing elevated levels of As, amongst other heavy metals. Due to its cost-effective feature and highly effective response, the adsorption technique is preferred over any other technique in removal of a variety of heavy metals. It has been very effective in bringing down the As content to less than $10 \mathrm{mg} / \mathrm{L}$ and the effectiveness can be monitored by a variety of characteristics. Column adsorption is most common method of adsorption used over a diverse range of chemicals to perform a multitude of functions. Adsorbents such as chelating materials, activated carbons and zeolites have been widely used for removing heavy metals including As. However, conventional adsorbents have limited efficiency and capacity. On passing the contaminated water through such columns containing adsorbents, the target metal gets adsorbed and the rest of the water is filtered out. However, after a definite period of use or definite volume of processing, the pores in the adsorption sites may all get blocked and columns would need to be replaced with new ones. Some of the common adsorbents used for As removal are activated alumina (AA), iron-coated sand, granular ferric hydroxide, indigenous cartridges and filters. The efficiency of these media also depends on the oxidising agents that oxidise the As to higher state which in turn makes adsorption easier. Recently, with the emergence of nano-technology, many nano adsorbents have emerged to be highly effective and highly efficient in arsenic removal as compared to the conventional adsorbents. These adsorbents, which are mostly carbon based, such as Carbon Nano-Tubes(CNTs) or Graphene, or polymer type such as polymer layered silicate nanocomposites, offer high sorption capacities and easy removal of the adsorbed material and these two factors together help in making this technology cost-effective.

In India Dr. Nalini Sankararamakrishnan, Facility for Ecological and Analytical testing, Indian Institute of Technology, Kanpur, has done multiple studies on devising cost-effective ways of As removal from potable water. The team under the professor has carried out multiple studies for synthesis of $\mathrm{FeO}$ coated/ $\mathrm{Fe}$ doped chitosan adsorbent, designing of domestic filter, and field analysis of sludge and wastewater (DST-gov-in, 2019). Also, another project i.e. Development of Arsenic adsorbing polymeric beads and their performance study in packed bed columns and Development of prototype systems to produce Arsenic-free safe drinking water under the guidance of Prof. Priyabrata Sarkar, Department of Polymer Science and Technology, University of Calcutta. This method focuses on severe capacity of As adsorbing bed which has $15.5 \mathrm{mg} / \mathrm{g}$ of As $5+$ on the basis of nano-alumina scattered in poly-acrylamide. Also there is ceramic filter candle having adsorbent in polymer for As removal. There are similar many other projects too being run in India with adsorption as a base technique to filter out arsenic from ground water.

\section{Conclusion}

Arsenic contamination is a very severe problem in groundwater. The paper thus concludes that the permissible limit of $50 \mu \mathrm{g} / \mathrm{l}$ or $0.05 \mathrm{mg} / \mathrm{l}$. set by the government of India is dangerously higher than the WHO guidelines of $0.01 \mathrm{mg} /$ especially considering the hot and humid climate of India which results in higher per capita consumption of water for drinking purposes. Further, the dominant cause of release of As into the groundwater, among other causes, is attributed to the reductive dissolution of the Fe and Al oxides. The states of West Bengal, Bihar, Uttar Pradesh and Gujarat are the worst affected by the arsenic contamination in India. Among these, the districts plagued in the states of Uttar Pradesh and Bihar need special care since the exposed population in 
these states have seriously low-income levels and scarce access to quality health services. Skin hardening, skin lesions, lesions in digestive tract and cancer are some of the common occurrences amongst the people affected by arsenic contamination. While the co-precipitation technique of removing arsenic from contaminated water is highly expensive, the chemical oxidative techniques, when used in conjunction with bacterial presence shows promising results. Presently, the most widely used technique for treatment of arsenic contaminated water is the adsorption. Recent innovations in the structure and composition of adsorbents using charcoal show highly efficient results. Besides removal, the safe disposal of extracted arsenic is common challenge for all the arsenic treatment methods.

\section{References}

Bibi, S., Kamran, M.A., Sultana, J. and Farooqi, A., 2017. Occurrence and methods to remove arsenic and fluoride contamination in water. Environmental Chemistry Letters, Vol. 15, No. 1, pp.125-149.

Bissen, M. and Frimmel, F.H., 2003. Arsenic-a review. Part I: occurrence, toxicity, speciation, mobility. Acta Hydrochimica et Hydrobiologica, Vol.31, No. 1, pp. 9-18. https://doi.org/10.1002/aheh.200390025

Borba, R.P., Figueiredo, B.R., Rawlins, B. and Matschullat, J., 2003. Geochemical distribution of arsenic in waters, sediments and weathered gold mineralized rocks from Iron Quadrangle, Brazil. Environmental Geology, Vol. 44, No. 1, pp.39-52.

Brown R.G. KG, 2002, Arsenic, drinking water, and health: a position paper of the American Council on Science and Health, RegulToxicolPharmacol Vol. 36, pp. 162-174.

Centeno, J.A., Mullick, F.G., Martinez, L., Page, N.P., Gibb, H., Longfellow, D., Thompson, C., and Ladich, E.R., 2002, Environmental Health Perspectives, Vol. 110, No. 5, pp. 883-886. doi: 10.1289/ehp.02110s5883

Chwirka, J.D., Thomson, B.M. and Stomp III, J.M., 2000. Removing arsenic from groundwater. Journal $\square$ American Water Works Association, Vol. 92, No. 3, pp.79-88.

Clifford, D.A. and Ghurye, G.L., 2002. Metal-oxide adsorption, ion exchange, and coagulation-microfiltration for arsenic removal from water. Environmental Chemistry of Arsenic, pp. 217-245.

Duxbury, J.M., Mayer, A.B., Lauren, J.G. \& Hassan, N., 2003. Food chain aspects of arsenic contamination in Bangladesh: Effects on quality and productivity of rice, Journal of Environmental Science and Health, Part A: Toxic/Hazardous Substances and Environmental Engineering, Vol. 38, No. 1, pp. 61-69

Edition, F., 2011. Guidelines for drinking-water quality. WHO Chronicle, Vol. 38, No. 4, pp.104-8.

Escobar, M.O., Hue, N.V. and Cutler, W.G., 2006. Recent developments on arsenic: contamination and remediation. Recent Research Developments in Bioenergetics, Vol. 4, pp.1-32.

Ferguson, J.F. and Gavis, J., 1972. A review of the arsenic cycle in natural waters. Water Research, Vol. 6, No. 11, pp.1259-1274.

Fields, K.A., Chen, A.S. and Wang, L., 2000. Arsenic removal from drinking water by coagulation/filtration and lime softening plants. Washington: National Risk Management Research Laboratory, Office of Research and Development, US Environmental Protection Agency.

Hossain, M.A., Sengupta, M.K., Ahamed, S., Rahman, M.M., Mondal, D., Lodh, D., Das, B., Nayak, B., Roy, B.K., Mukherjee, A. and Chakraborti, D., 2005. Ineffectiveness and poor reliability of arsenic removal plants in West Bengal, India. Environmental Science \& Technology, Vol. 39, No. 11, pp.4300-4306.

Hossain, M.A., Rahman, M.M., Murrill, M., Das, B., Roy, B., Dey, S., Maity, D. and Chakraborti, D., 2013. Water consumption patterns and factors contributing to water consumption in arsenic affected population of rural West Bengal, India. Science of the Total Environment, Vol. 463, pp.1217-1224.

Matschullat, J., 2000. Arsenic in the geosphere-a review. Science of the Total Environment, Vol. 249, No. 1-3, pp.297-312.

Gallard, H. and von Gunten, U. 2002. Chlorination of natural organic matter: kinetics of chlorination and of THM formation., Water Research, Vol. 36, pp. 65-74.

Guo, H., Zhang, B., Li, Y., Berner, Z., Tang, X., Norra, S. and Stüben, D., 2011. Hydrogeological and biogeochemical constrains of arsenic mobilization in shallow aquifers from the Hetao basin, Inner Mongolia. Environmental Pollution, Vol. 159, No. 4, pp. 876-883.

Gopal, B., 2012. Water resources and sustainable development: Issues and approaches to management-an Indian perspective. International Journal of Ecology and Environmental Sciences, Vol. 38, No. 2-3, pp.133-160.

"http://www.dst.gov.in/scienfic-programme/t-d-w.htm," [Online]. Available: http://www.dst.gov.in/scienfic- programme/t-dw.htm. [Accessed 29 june 2019].

https://www.hindustantimes.com," 25 july 2019. [Online]. Available: • https://www.hindustantimes.com/india-news/1-47- croreindians-drink-arsenic-contaminated-water/story- rMSgUDyI4HzELCRRaICAYK.html. [Accessed 25 july 2019].

"jalshkti," 27 july 2019. [Online]. Available: https://jalshakti- ddws.gov.in/sites/default/files/Annual_report_2018_19_dws.pdf. [Accessed 27 july 2019].

Matschullat, J., 2000. Arsenic in the geosphere-a review. Science of the Total Environment, Vol. 249, No. 1-3, pp.297-312.

Shankar, S. and Shanker, U., 2014. Arsenic contamination of groundwater: a review of sources, prevalence, health risks, and strategies for mitigation. The Scientific World Journal, Vol. 2014, Article 304524. https://doi.org/10.1155/2014/304524 
Smedley, P.L. and Kinniburgh, D.G., 2002. A review of the source, behaviour and distribution of arsenic in natural waters. Applied Geochemistry, Vol. 17, No. 5, pp.517-568.

Wang, L., Kou, M.C., Weng, C.Y., Hu, L.W., Wang, Y.J. and Wu, M.J., 2012. Arsenic modulates heme oxygenase-1, interleukin6 , and vascular endothelial growth factor expression in endothelial cells: roles of ROS, NF- $\mathrm{BB}$, and MAPK pathways. Archives of Toxicology, Vol. 86, No. 6, pp.879-896.

Welch, A.H., Lico, M.S. and Hughes, J.L., 1988. Arsenic in ground water of the western United States. Groundwater, Vol. 26, No. 3, pp.333-347.

World Health Organisation," WHO, 15 February 2018. [Online].Available:https://www.who.int/news-room/factsheets/detail/arsenic. [Accessed 12 July 2019].

WHO, "Newsroom," WHO, February 2018. [Online]. Available: www.who.int/news-room/fact- sheets/detail/arsenic. [Accessed July 2019].

\section{Biographical notes}

Rishabh Tiwari, Satwik, Prateek Khare and Satyam Rai are all from the Department of Chemical Engineering, Madan Mohan Malaviya University of Technology, Gorakhpur, Uttar Pradesh, India. 